\author{
Нікішина О.В. \\ доктор економічних наук, старший науковий співробітник \\ завідувач відділу ринкових механізмів та структур \\ Інститут проблем ринку та економіко-екологічних досліджень НАН України \\ Французький бульвар, 29, м. Одеса, Україна, 65044 \\ E-mail: ksenkych@gmail.com \\ ORCID ID: 0000-0002-7172-3551
}

\title{
ТЕОРЕТИЧНИЙ БАЗИС МЕХАНІЗМІВ ФОРМУВАННЯ ЕФЕКТИВНОЇ ЛОГІСТИКИ ТОВАРНИХ РИНКІВ *
}

Стаття присвячена обґрунтуванню теоретичних засад механізмів фрормування ефективної логістики товарних ринків на базі відтворювального підходу. Виділено чотири підходи до визначення сутності економічної категорії «механізм», запропоновано авторське визначення категорії «механізм формування ефективної логістики товарних ринків» на основі комплексного підходу. Проведено порівняльний аналіз механізмів формування ринкової логістики різних типів (логістичної взаємодії, управлінського та комплексного). Досліджено взаємозв'язки та взаємодії логістичних механізмів на мікро- та макрорівні, взаємопроникнення різних методів і способів управління у механізми різних типів. Наголошено, що логістична компонента інтегрована у певні організаційні та економічні механізми управління розвитком національної економіки та її секторів. Розроблено теоретико-методичний базис комплексного механізму фрормування ефективної логістики товарних ринків, обґрунтовано доцільність управлінського впливу держави на логістичні «розриви» потокових процесів та провідні ланки товарних ринків. Розроблено методичні положення діагностики ефективності регулювання провідних ланок ринкових ланцюгів на основі синтезу відтворювального й регуляторного підходів.

Ключові слова: товарний ринок, логістичний ланцюг, механізм, провідна ланка, регулювання, ефективна логістика, додана вартість.

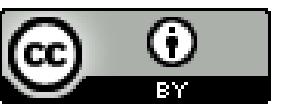

This work is licensed under a Creative Commons Attribution 4.0 International License http://creativecommons.org/licenses/by/4.0/
Постановка проблеми та її зв'язок з важливими науковими та практичними завданнями. В умовах системної кризи важливою умовою відтворювального розвитку національної економіки є ефективне функціонування логістичних ланцюгів товарних ринків (далі - ЛЛТР), у ланках яких відбувається процес продукування й розподілу доданої вартості, що $є$ внутрішнім ресурсом розвитку країни. Логістика має великий потенціал економічної ефективності та чинить значний вплив на розвиток як товарних ринків, так і економіки в цілому. Завдання формування ефективної логістики товарних ринків, орієнтованої на оптимізацію ланкової доданої вартості та розширене відтворення товароруху в ринку, передбачає розробку та впровадження певних механізмів (організаційних, координаційних, соціально-економічних, управлінських, інституційних та ін.) в логістичних системах різних рівнів (мікро-, мезо та макрорівня). Теоретичним базисом побудови таких механізмів постає визначення їх природи, сутнісних характеристик, компонентів і функцій крізь призму цільових орієнтирів відтворювальної логістики товарних ринків.

Нині в економічній літературі немає єдиного універсального визначення терміну «механізм», який вживається ученими у різних трактуваннях: механізм розвитку національної економіки, іiї секторів і певних ринків; механізм підвищення ефективності і конкурентоспроможності економіки, її секторів, підприємств; механізм державного регулювання певними сферами діяльності тощо. Значна множина визначень вихідної категорії та її багатоаспектність свідчить, з одного боку, про іiі прикладну значимість для вирішення багатьох важливих завдань відтворювальнологістичного розвитку економіки та різних її сфер, 3 іншого, про певну термінологічну невизначеність, яка потребує роз'яснення та нових досліджень.

Аналіз останніх публікацій по проблемі. Теоретичні основи економічних механізмів висвітлені в працях Бичкової А.Н. [1], Гурвіца Л., Ізмалкова С., Соніна К. [2], Кульмана А. [3], Мочерного С.В. [4], Чаленко А.Ю. [5] та ін. учених. Особливості організаційно-економічного забезпечення логістичних процесів на мікрорівні досліджували Гурч Л.М. [6], Дікань В.Л. [7], Єлетенко О.В. [8], Крикавський Є.В., Пономаренко В.С. [9] та ін. науковці.

Водночас недостатньо дослідженими є теоре-

*Публікацію підготовлено в межах виконання НДР «Формування ефективної логістики товарних ринків» (№ державної реєстрації 0119U000227). 
тичні засади механізмів формування ринкової логістики на макрорівні, а також методичне забезпечення діагностики ефективності випливу регуляторних заходів на стан ЛЛТР.

Формулювання цілей дослідження. Мета статті - розробка теоретичного базису комплексного механізму формування ефективної логістики товарних ринків та методичних положень діагностики ефективності регулювання провідних ланок ЛЛТР, як науково-методичного підгрунтя для формування програм і стратегій логістичного розвитку стратегічних ринків.

Виклад основних результатів та їх обгрунтування. Термін «механізм» (гр. «тесhanе»- зброя, машина) С.В. Мочерний трактує як систему, пристрій, засіб, спосіб, що визначають порядок певного виду діяльності $[4$, с.355]. Учений виділяє категорію «господарський механізм» як «систему основних форм, методів і важелів використання економічних законів, вирішення суперечностей суспільного способу виробництва, реалізації власності, а також всебічного розвитку людини й узгодження іiї інтересів 3 інтересами колективу, класу, суспільства» [4, с.269]. Організаційно-економічні механізми є складовою господарського механізму. Філософські енциклопедичні ресурси визначають категорію «механізм» як спосіб або послідовність певного набору цілеспрямованих дій, націлених на досягнення певної мети, й одночасно засіб, за допомогою якого ці дії здійсню- ються [10]. Вважаємо дане визначення є прийнятним для встановлення головних акцентів терміну «механізм» у логістично-ринковому вимірі.

Проведені нами дослідження категорійної сукупності дефініції «механізм» дозволили виокремити чотири наукові підходи, які дозволяють об'єднати різноманітні визначення у групи (таблиця 1):

1) організаційно-координаційний;

2) управлінський;

3) еволюційний;

4) комплексний підходи.

На практиці найбільш поширеними є перші два наукові підходи. У межах організаиійнокоординаційного підходу науковці визначають механізм як інструмент взаємодії. Найбільш відомими $є$ розробки Лео Гурвіца, який трактує механізм як «взаємодію між суб'єктами і центром», що складається із трьох етапів (див. табл. 1). Учений сформулював завдання формального аналізу механізмів в теорії ігор між агентами та їх економічними інтересами; ефективність механізмів він зводить до аналізу ефективності рівноваги в цих іграх [2]. Дослідження Чаленко А.Ю. доводять нерозривний зв'язок і підпорядкованість механізму процесу. На його думку, особливістю механізму $є$ наявність процесу. Сам механізм учений визначає як «сукупність ресурсів економічного процесу та способів їх поєднання» [5].

Таблиця 1

Сутність економічної категорії «механізм» за різними науковими підходами*

\begin{tabular}{|c|c|c|}
\hline Підхід & Автори & Визначення категорій \\
\hline \multirow{2}{*}{$\begin{array}{l}\text { Енциклопедичні } \\
\text { ресурси: } \\
\text { Механізм } \\
\text { (гр. «тессhапе» - } \\
\text { зброя, машина) }\end{array}$} & $\begin{array}{l}\text { С.В. Мочерний } \\
{[4, \text { c. } 355]}\end{array}$ & $\begin{array}{l}\text { 1) система, пристрій, спосіб, що визначають порядок певного } \\
\text { виду діяльності; } \\
\text { 2) внутрішній пристрій машини, устаткування тощо - система } \\
\text { певних ланок та елементів, що приводить їх у дію. }\end{array}$ \\
\hline & $\begin{array}{l}\text { Філософський } \\
\text { словник } \\
{[10]}\end{array}$ & $\begin{array}{l}\text { Спосіб або послідовність певного набору иілеспрямованих дій, } \\
\text { націлених на досягнення певної мети, й одночасно засіб, за до- } \\
\text { помогою якого ці дії здійснюються. }\end{array}$ \\
\hline \multirow{2}{*}{$\begin{array}{l}\text { 1. Організаційно- } \\
\text { координаційний } \\
\text { (механізм як ін- } \\
\text { струмент взаємо- } \\
\text { діï) }\end{array}$} & $\begin{array}{l}\text { Лео Гурвіц } \\
\text { (Leo Hurwicz) } \\
\text { [2] }\end{array}$ & $\begin{array}{l}\text { Взаємодія між суб 'єктами і иентром, що включає три етапи: } \\
\text { (1) кожний суб'єкт окремо надсилає центру повідомлення; } \\
\text { (2) центр, отримавши повідомлення, розраховує очікуваний ре- } \\
\text { зультат; (3) центр оголошує результат і за необхідності впрова- } \\
\text { джує його в практику. }\end{array}$ \\
\hline & $\begin{array}{l}\text { Чаленко А.Ю. } \\
\text { [5] }\end{array}$ & $\begin{array}{l}\text { Сукупність ресурсів економічного процесу і способів їх поєд- } \\
\text { нання. Особливість: наявність процесу і нерозривний зв'язок і } \\
\text { підпорядкованість механізму процесу. }\end{array}$ \\
\hline $\begin{array}{l}\text { 2. Управлінський } \\
\text { (механізм як ін- } \\
\text { струмент впливу) }\end{array}$ & $\begin{array}{l}\text { Слетенко О.В. } \\
{[8, \text { с.496] }}\end{array}$ & $\begin{array}{l}\text { Механізм управління логістичною системою - сукупність науко- } \\
\text { вих методів та засобів, які впливають на логістичні процеси під- } \\
\text { приємства, регулюють, аналізують та вдосконалюють їх, здійс- } \\
\text { нюють моніторинг, прогнозування, планування та корегування } \\
\text { руху логістичних потоків. }\end{array}$ \\
\hline $\begin{array}{l}\text { 3. Еволюційний } \\
\text { (механізми- } \\
\text { закономірності) }\end{array}$ & $\begin{array}{l}\text { А. Кульман } \\
{[3, \text { с.43] }}\end{array}$ & $\begin{array}{l}\text { Послідовність взаємопов’язаних економічних явищ, що має } \\
\text { об’єктивний характер і може пояснити певний природний ево- } \\
\text { люційний процес розвитку явища (механізми рівноваги попиту й } \\
\text { пропозиції, ціноутворення, впливу світових цін на макроеконо- } \\
\text { мічні показники країни, економічних циклів тощо). }\end{array}$ \\
\hline
\end{tabular}


Продовження табл.1

\begin{tabular}{|c|c|c|}
\hline Підхід & Автори & Визначення категорій \\
\hline & $\begin{array}{l}\text { С.В. Мочерний } \\
{[4, \text { c. } 358]}\end{array}$ & $\begin{array}{l}\text { Механізм використання економічних законів - комплекс заходів, } \\
\text { спрямованих на подолання конфліктно-антагоністичних форм ро- } \\
\text { звитку суперечностей (які пронизують закони), формування нау- } \\
\text { ково-обгрунтованої системи управлінської діяльності різних } \\
\text { суб'єктів (держави, наднаціональних органів та ін.) на рівні } \\
\text { об’єктів, окремих явищ і процесів передусім через реалізацію } \\
\text { форм економічної політики і використання правових та адмініст- } \\
\text { ративних важелів регулювання народного господарства. }\end{array}$ \\
\hline \multirow{2}{*}{$\begin{array}{l}\text { 4. Комплексний } \\
\text { (синтез різних під- } \\
\text { ходів) }\end{array}$} & $\begin{array}{l}\text { Дикань В.Л., } \\
\text { Заєць Г.П. } \\
\text { [7, с.12] }\end{array}$ & $\begin{array}{l}\text { Механізм організачійно-економічного забезпечення логістичної } \\
\text { системи - впорядкована сукупність засобів і методів впливу на } \\
\text { елементи логістичної системи, взаємопов'язаних прямими і зворо- } \\
\text { тними зв'язками з організації та управління потоками, спрямова- } \\
\text { них на ефективне функціонування та задоволення потреб кінцевих } \\
\text { споживачів результатами функціонування логістичної системи. }\end{array}$ \\
\hline & $\begin{array}{l}\text { А.Н. Бичкова } \\
{[1, \text { с.42] }}\end{array}$ & $\begin{array}{l}\text { Економічний механізм - це сукупність способів управління та вза- } \\
\text { ємодії суб'єктів, цільовою функцією якого є раціональне господа- } \\
\text { рювання та формування стійких закономірностей у розвитку еко- } \\
\text { номіки }\end{array}$ \\
\hline
\end{tabular}

* Узагальнено авторами з використанням джерел $[1-5,7,8,10]$

У межах управлінського підходу учені розкривають природу механізму в контексті інструментів впливу на економічні процеси, як правило, акцентуючи увагу на функціях управління. Так, О.В. Слетенко визначає механізм управління мікрологістичною системою як «сукупність наукових методів та засобів, які впливають на логістичні процеси підприємства, регулюють, аналізують та вдосконалюють їх, здійснюють моніторинг, прогнозування, планування та корегування руху логістичних потоків» [8, с.496]. Управлінського підходу до визначення сутності механізму формування логістичної стратегії дотримуються також В.С. Пономаренко, К.М. Таньков і T.I. Лепейко [9].

В теорії механізмів, окрім організаційного та управлінського підходів, існує еволюційний, у межах якого учені визначають механізм як «послідовність взаємопов'язаних економічних явищ, що має об'єктивний характер і може пояснити певний еволюційний процес розвитку явища» [3, с.43]. Прихильником даного підходу є французький учений Анрі Кульман. До механізмів-закономірностей він відносить, зокрема, механізми рівноваги попиту й пропозиції, ціноутворення, економічних циклів тощо. А. Кульман виокремлює механізми відкритого (результатом їх дії є нове явище) та закритого типів (відтворюють вихідне явище в певних масштабах) [3, c.43]. Механізм використання економічних законів виділяє також С.В. Мочерний (див. табл. 1).

На підставі вивчення існуючих досліджень ми виділили комплексний підхід до ідентифікації категорії «механізм», який передбачає синтез різних наукових підходів (див. табл. 1). Так, у визначенні механізму організаційно-економічного забезпечення логістичної системи наявний синтез організаційнокоординаційного та управлінського підходів [7, с.12]. Визначення економічного механізму, запропоноване А.Н. Бичковою, є найбільш універсальним, органічно поєднуючи три підходи. На ii думку, економічний механізм - це сукупність способів управління та взаємодії суб'єктів, цільовою функцією якого є раціональне господарювання та формування стійких закономірностей у розвитку економіки [1, с.42].

У даному дослідженні використаємо саме комплексний niдxid до теоретичного осмислення та подальшої структуризації механізмів формування ефективної логістики товарних ринків. На практиці механізми різних типів взаємодіють між собою, переплітаються методи і способи впливу та взаємодії, тому найбільш обгрунтованим підходом до їх системного дослідження, на наш погляд, є комплексний, синтезуючий у єдину площину характеристики різних механізмів для отримання цілісного уявлення про їх природу та структуру.

Запропоновані в табл. 1 підходи, по суті, формують типологію механізмів (організаційнокоординаційні, управлінські, закономірності та комплексні), що може бути застосована у різних сферах дослідження, забезпечуючи при цьому його повноту та достовірність. У сфері ринкової логістики визначені типи механізмів набувають специфічних властивостей та відмінних рис. Порівняльна характеристика різних типів механізмів формування логістики товарного ринку наведена в таблиці. 2.

Механізми логістичної взаємодії (організаційно-координаційні) передбачають тісний взаємозв'язок і взаємодію суб'єктів логістичних ланцюгів, що забезпечує оптимізацію логістичних процесів, в основному, внутрішньо- та міжланкових. Відмінними рисами механізмів даного типу є тісний зворотний зв'язок суб'єктів взаємодії 3 керуючим елементом (наприклад, логістичним центром, провайдером), мотиваційний характер методів взаємодії. Головною метою механізмів логістичної взаємодії $\epsilon$ узгодження економічних інтересів учасників ЛЛТР. Впровадження цих механізмів здійснюється за допомогою інформаційних методів, договірних відносин, логістичного аутсорсингу, економічної інтеграції та ін. 


\section{Порівняльна характеристика різних типів механізмів формування} логістики товарного ринку ${ }^{*}$

\begin{tabular}{|c|c|c|c|}
\hline $\begin{array}{c}\text { Типи / } \\
\text { Особливості }\end{array}$ & $\begin{array}{c}\text { Механізми логістичної } \\
\text { взасмодії }\end{array}$ & $\begin{array}{c}\text { Механізми управлінського } \\
\text { впливу }\end{array}$ & $\begin{array}{c}\text { Комплексний механізм } \\
\text { формування ЛЛТР }\end{array}$ \\
\hline 1. Сутність & $\begin{array}{l}\text { Взаємозв’язок і логістична } \\
\text { взаємодія суб’єктів, що забез- } \\
\text { печує розвиток об’єкту }\end{array}$ & $\begin{array}{l}\text { Сукупність інструментів і } \\
\text { заходів, що цілеспрямовано } \\
\text { впливають на розвиток } \\
\text { об’єкту }\end{array}$ & $\begin{array}{l}\text { Управління та логістична } \\
\text { взаємодія суб'єктів для дося- } \\
\text { гнення цільових орієнтирів } \\
\text { ЛЛТР }\end{array}$ \\
\hline $\begin{array}{l}\text { 2.Відмінні } \\
\text { риси }\end{array}$ & $\begin{array}{l}\text { 1. Тісний зворотній зв’язок } \\
\text { суб’єктів взаємодії з керую- } \\
\text { чим елементом } \\
\text { 2. Мотиваційний характер } \\
\text { методів взаємодії } \\
\text { 3. Головна мета - узгодження } \\
\text { економічних інтересів учас- } \\
\text { ників ЛЛТР }\end{array}$ & $\begin{array}{l}\text { 1. Слабкий зворотній зв’язок } \\
\text { учасників ЛЛТР з керуючим } \\
\text { елементом } \\
\text { 2. Мотиваційно-примусові } \\
\text { методи управління } \\
\text { 3. Головна мета - ефективне } \\
\text { управління наскрізним мате- } \\
\text { ріальним потоком в ринку }\end{array}$ & $\begin{array}{l}\text { 1. Різний ступінь зворотного } \\
\text { зв’язку суб'єктів ЛЛТР з ке- } \\
\text { руючим елементом } \\
\text { 2. Поєднання мотиваційних і } \\
\text { примусово-обмежувальних } \\
\text { методів } \\
\text { 3. Головна мета - оптимізація } \\
\text { ринкової доданої вартості та } \\
\text { структурної будови ЛЛТР на } \\
\text { засадах пріоритетності ЕІ } \\
\text { держави, як носія інтересів } \\
\text { суспільства }\end{array}$ \\
\hline 3. Об’єкт & $\begin{array}{l}\text { Логістичні процеси, в основ- } \\
\text { ному, внутрішньо- та міжлан- } \\
\text { кові }\end{array}$ & $\begin{array}{l}\text { Потокові процеси товарних } \\
\text { ринків, як міжланкові, так і } \\
\text { міжланцюгові }\end{array}$ & $\begin{array}{l}\text { Різноманітні потокові проце- } \\
\text { си товарних ринків: внутріш- } \\
\text { ньо- та міжланкові, міжлан- } \\
\text { цюгові. }\end{array}$ \\
\hline 4. Суб'єкти & $\begin{array}{l}\text { Учасники ЛЛТР, як окремих } \\
\text { ланок, так і різних ланок ри- } \\
\text { нкового ланцюга }\end{array}$ & $\begin{array}{l}\text { Учасники ЛЛТР на мікро-, } \\
\text { мезо та макрорівнях, а також } \\
\text { держава }\end{array}$ & $\begin{array}{l}\text { Учасники ЛЛТР на мікро-, } \\
\text { мезо та макрорівнях, а також } \\
\text { держава }\end{array}$ \\
\hline $\begin{array}{l}\text { 5. Керуючий } \\
\text { елемент }\end{array}$ & $\begin{array}{l}\text { Суб’єкти ЛЛТР, логістичні } \\
\text { провайдери; } \\
\text { може бути відсутній }\end{array}$ & $\begin{array}{l}\text { Великі логістичні провайде- } \\
\text { ри, корпоративні управлін- } \\
\text { ські центри, профільні інсти- } \\
\text { туції, держава (може бути і } \\
\text { суб'єктом, і керуючим еле- } \\
\text { ментом) }\end{array}$ & $\begin{array}{l}\text { Великі логістичні провайдери, } \\
\text { профільні інституції, що ді- } \\
\text { ють на ринку, держава в особі } \\
\text { органів влади різних рівнів }\end{array}$ \\
\hline $\begin{array}{l}\text { 6. Доміную- } \\
\text { чий інтерес }\end{array}$ & $\begin{array}{l}\text { Економічні інтереси (EI) } \\
\text { суб'єктів господарювання }\end{array}$ & $\begin{array}{l}\text { Економічні інтереси } \\
\text { суб’єктів ЛЛТР та держави }\end{array}$ & $\begin{array}{l}\text { Пріоритет ЕІ держави, як но- } \\
\text { сія інтересів суспільства, над } \\
\text { інтересами суб'єктів певних } \\
\text { ланок ЛЛТР }\end{array}$ \\
\hline $\begin{array}{l}\text { 7. Методи i } \\
\text { способи вза- } \\
\text { смодї̈ } \\
\text { (впливу) }\end{array}$ & $\begin{array}{l}\text { Інформаційні, договірні від- } \\
\text { носини, перерозподіл функцій } \\
\text { (аутсорсиинг), торги, інтегра- } \\
\text { ція тощо }\end{array}$ & $\begin{array}{l}\text { Соціально-економічні, інвес- } \\
\text { тиційно-інноваційні, фінан- } \\
\text { сові, інституціональні, при- } \\
\text { родоохоронні, адаптаційні, } \\
\text { трансфертні, антикризові } \\
\text { тощо. }\end{array}$ & $\begin{array}{l}\text { Поєднання організаційних } \\
\text { методів (інформаційних, кон- } \\
\text { трактації, аутсорсингу, ДПП) } \\
\text { з соціально-економічними, } \\
\text { адміністративними та інсти- } \\
\text { туційними методами. }\end{array}$ \\
\hline
\end{tabular}

*Сформовано автором 3 використанням джерел $[1,3]$

Механізми управлінського впливу складаються із сукупності інструментів та заходів, що цілеспрямовано впливають на розвиток об'єкту - потокові процеси товарних ринків, як міжланкові, так і міжланцюгові (див. табл. 2). Особливістю управлінських механізмів $\epsilon$ слабкий зворотній зв'язок учасників ЛЛТР із керуючим елементом, застосування мотиваційно-примусових методів управління. Суб'єктами управління в механізмах даного типу є учасники ЛЛТР на різних рівнях (мікро-, мезо- та макрорівнях), а також держава, яка може бути як суб'єктом логістичних процесів, так і їх регулятором.

Окрім держави, функції керуючого елементу можуть виконувати великі логістичні провайдери, корпоративні управлінські центри, профільні та інші інституції. Головною метою впровадження управлінських механізмів $\epsilon$ ефективне управління наскрізним матеріальним потоком на засадах узгодження економічних інтересів суб'єктів ЛЛТР та держави. Для реалізації цих механізмів на практиці використовують широкий спектр методів і способів впливу, зокрема, соціально-економічні, інвестиційно-інноваційні, фінансові, антикризові, адаптаційні тощо.

Комплексний механізм формування логістики товарного ринку передбачає управління та логістичну взаємодію суб'єктів для досягнення цільових орієнтирів ефективної логістики - оптимізації ринкової доданої вартості та структурної будови ЛЛТР на 
засадах пріоритетності економічних інтересів держави, як носія інтересів суспільства (див. табл. 2). Відмінною рисою комплексного механізму є різний ступінь зворотного зв'язку суб'єктів ЛЛТР з керуючим елементом, поєднання мотиваційних і примусовообмежувальних методів для ефективного управління різноманітними потоковими процесами товарних ринків (внутрішньо- і міжланковими в межах одного логістичного ланцюга, а також міжланцюговими). В комплексному механізмі функції керуючого елементу можуть виконувати великі логістичні провайдери, профільні інституції ринку, держава в особі органів влади різних рівнів. Реалізація даного механізму передбачає органічне поєднання організаційних методів 3 соціально-економічними, адміністративними та інституційними методами впливу на об'єкт управління.

На підставі проведеного дослідження концептуальної сутності економічної категорії «механізм» та порівняльного аналізу різних типів механізмів формування ЛЛТР сформулюємо авторське визначення дефініції. Механізм формування ефективної логістики товарних ринків інтерпретуємо на основі комплексного підходу як впорядковану сукупність способів і методів управління та логістичної взаємодії суб'єктів ЛЛТР, головною метою якого є оптимізація загальної ринкової доданої вартості та структурної будови ринкових ланцюгів, а також забезпечення просторово-часового балансування товарних потоків.
Запропоноване авторське визначення вихідної дефініції синтезує в єдину наукову площину організаційно-координаційний, управлінський та еволюційний підходи (див. табл. 1), акцентуючи увагу на відтворювальну мету ефективної логістики та іiі важливу роль у збалансуванні попиту та пропозиції товарів у визначених просторових і часових межах певного ринку. Слід зазначити, що ефективна логістика ринку має значний потенціал трансформаційного впливу на ринкову рівновагу шляхом скорочення терміну збалансування попиту й пропозиції в результаті гнучкого регулювання параметрів товарних потоків залежно від цінових коливань. Дане твердження на основі модифікованої моделі ринкової рівноваги Еванса доведено авторами в праці [11]. Відтак, розбудова ефективної логістики товарних ринків може сприяти формуванню стійких закономірностей у балансуванні попиту й пропозиції шляхом впровадження комплексних механізмів.

На практиці механізми формування ефективної логістики різних типів (див. табл. 2) проявляються на різних рівнях економічної системи. Для більш глибокого дослідження теоретичних засад механізмів визначимо їх взаємозв'язки та взаємодії на двох базових рівнях: (1) мікрорівні, тобто в аспекті традиційної логістики підприємств; (2) макрорівні, тобто в площині логістики товарного ринку. Взаємозв'язок між механізмами формування ефективної логістики на мікро- та макрорівнях відображено на рис. 1.

\begin{tabular}{|c|c|c|c|}
\hline Piвні / & $\begin{array}{c}\text { Мікрорівень } \\
\text { (логістика підприємств) }\end{array}$ & $\begin{array}{c}\text { Макрорівень } \\
\text { (логістика товарного ринку) }\end{array}$ & \\
\hline $\begin{array}{l}\text { 1. Логістичні } \\
\text { (всередині підприємств) } \\
\text { 2. Логістичної взаємодії (лан- } \\
\text { кові, міжланкові) }\end{array}$ & $\begin{array}{l}\text { Аналіз АВC-XYZ, мікроло- } \\
\text { гістичні технології МRP, } \\
\text { KANBAN, «Оптимізована } \\
\text { виробнича технологія» тा } \\
\text { ін. }\end{array}$ & $\begin{array}{l}\text { Контрактація, логістичний аут- } \\
\text { сорсинг, кооперація, інтеграція, } \\
\text { інформаційні механізми, держа- } \\
\text { вно-приватне партнерство та ін/ } \\
\text { логістична технологія 7R }\end{array}$ & 胥 \\
\hline $\begin{array}{l}\text { 3. Управлінські } \\
\text { (всередині підприємств, ланок, } \\
\text { міжланкові) } \\
\text { 4. Комплексні (міжланкові, } \\
\text { міжланцюгові) }\end{array}$ & $\begin{array}{l}\text { 1. Планування } \\
\text { 2. Організація } \\
\text { 3. Мотивація } \\
\text { 4. Координація } \\
\text { 5. Регулювання } \\
\text { 6. Контроль }\end{array}$ & $\begin{array}{l}\text { 1. Механізми реалізації економі- } \\
\text { чної політики (структурно- } \\
\text { галузевої, інвестиційної, бюдже } \\
\text { тної, податкової та ін.) } \\
\text { 2. Механізми реалізації екологі- } \\
\text { чної та соціальної політики }\end{array}$ & 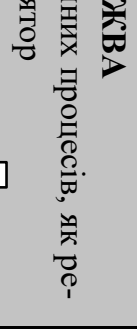 \\
\hline \multicolumn{4}{|c|}{ ІНСТИТУЦЙНЕ СЕРЕДОВИЩЕ } \\
\hline
\end{tabular}

Рис. 1. Взаємозв'язок між механізмами формування ефективної логістики

на мікро- та макрорівнях*

*авторська розробка

Безпосередньо логістичні механізми та інструменти застосовуються суб'єктами в мікрологістичних системах (на рівні підприємств) і включають традиційні логістичні технології (зокрема, MRP, KANBAN, «Оптимізована виробнича технологія», ABC-XYZ аналіз та ін.), які детально описані в теорії логістики [6]. Виняток складає комплексна логістична технологія $7 \mathrm{R}$ (забезпечення необхідним товаром, необхідної якості, кількості, в потрібний час та місце
3 мінімальними витратами, при необхідній якості обслуговування споживачів), яка може впроваджуватися як в мікро-, так і макрологістичних системах (див. рис. 1).

На макрорівні суб'єкти господарювання, державні та профільні інституції впроваджують «не логістичні» механізми та інструменти, які, окрім головного об'єкту управління (певні економічні процеси, сектори, товарні ринки, підтримка малих і серед- 
ніх підприємств тощо), прямо або опосередковано впливають на потокові процеси товарних ринків, структурну будову ЛЛТР. Відтак, логістична компонента інтегрована у певні організаційні та економічні механізми управління розвитком національної економіки та іiі секторів. Механізм формування ефективної логістики вбудований у загальний механізм управління товарними ринками, є динамічним і адаптивним, відповідає поточній моделі розвитку національної економіки.

Механізми логістичної взаємодії можуть реалізовуватися як суб'єктами господарювання (логістичний аутсорсинг, кооперація, інтеграція тощо), так і державою (наприклад, державно-приватне партнерство), яка в цьому випадку виступає учасником ЛЛТР та формує економічні відносини 3 ринковими суб'єктами на засадах узгодження державних і підприємницьких інтересів (див. рис. 1). 3 іншого боку, держава, як регулятор розвитку товарних ринків, формує відповідне інституційне середовище та розробляє механізми реалізації економічної, екологічної та соціальної політики, які, безумовно, регламентують потокові процеси товарних ринків, створюють сприятливі або обмежувальні умови для впровадження різних механізмів логістичної взаємодії.

Відтак, на практиці відбувається різновекторний вплив на процеси товароруху, з одного боку, механізмів управління та логістичної взаємодії, з іншого, механізмів формування логістики на мікро- та макрорівнях. В умовах такого складного взаємовпливу та взаємодії відбувається взаємопроникнення різних методів і способів управління у механізми різних типів, що дещо стирає їх межі та ускладнює процедуру їх чіткої систематизації.

На підставі вищезазначеного можна сформулювати таке гіпотетичне твердження: розробка та впровадження комплексних механізмів формування ефективної логістики певних товарних ринків передбачає тісну взаємодію, взаємодоповнення та координацію механізмів логістичної взаємодії та управління на мікро- та макрорівнях на засадах узгодження економічних інтересів суб'єктів господарювання, держави та споживачів, а також досягнення міжланкових консенсусів у матеріалопровідних ланцюгах ринку. В українських реаліях функцію координації складових комплексного механізму доцільно покласти на державні інституції (у тісній взаємодії з профільними інституціями ринку), спроможні спрямувати стихійні процеси логістизації стратегічних товарних ринків в пріоритетні для відтворювального розвитку економіки напрями відповідно до діючих стратегій і програм.

Управлінські механізми в мікрологістичних системах базуються на впровадженні основних функцій управління (див. рис. 1), зорієнтовані на оптимізацію локального матеріального потоку. Ученілогісти зазначають, що розробку, реалізацію та розвиток механізму формування логістичної стратегії (або механізму організаційно-економічного забезпечення логістичної системи) на підприємстві можна розглядати як інноваційний процес або логістичну інновацію [7, 9]. Це свідчить про значний потенціал логістичного менеджменту, як управлінської іннова- ції, у підвищенні конкурентоспроможності товаровиробників на ринку.

На макрорівні в ході розбудови логістичних ланцюгів певного товарного ринку теж впроваджуються базові функції управління, зорієнтовані на оптимізацію наскрізних потокових процесів та досягнення загальної (спільної) мети матеріалопровідного ланцюга - оптимізації ланцюгової доданої вартості. При цьому можливою є розбіжність локальних оптимумів цілей окремих ланок із глобальним оптимумом відтворювальної мети ЛЛТР [12, с. 100]. Цю проблему покликані вирішити комплексні механізми формування ефективної логістики товарних ринків.

На їх розробку, трансформацію та розвиток впливають діючі в державі механізми реалізації економічної, екологічної та соціальної політики, формуючи певне інституційне середовище для розвитку товарних ринків, у т.ч. і їх логістичних процесів (див. рис. 1). Господарський Кодекс України (ст. 10) виділяє 11 основних напрямів економічної політики: структурно-галузева, інвестиційна, амортизаційна, інституційних перетворень, цінова, антимонопольноконкурентна, бюджетна, податкова, грошовокредитна, валютна, зовнішньоекономічна [13]. Відповідно до напрямів економічної політики, доцільно виокремити 11 типів механізмів її реалізації (інвестиційний, ціновий, податковий, бюджетний і т.д.).

Механізми реалізації соціальної політики в частині захисту прав споживачів, заробітної плати і зайнятості населення, теж впливають на формування логістичних систем різних рівнів. Про важливість трудових ресурсів у розбудові ефективних логістичних ланцюгів свідчать результати нових досліджень учених, які до складу потокових процесів, поряд 3 базовим матеріальним потоком та відповідними йому інформаційним і фінансовим, включають трудові потоки [6]. 3 іншого боку, ефективна логістична система повинна бути ресурсозаощадливою та екологічно безпечною, що досягається, зокрема, механізмами реалізації екологічної політики (див. рис. 1). Відтак, маємо певний вплив загальнодержавних механізмів реалізації економічної, екологічної та соціальної політики на розробку та розвиток механізмів формування логістики на мікро- та макрорівні. Напрями впливу (стимулюючий, дестимулюючий, нейтральний) визначаються пріоритетами соціально-економічної політики держави.

Теоретичний базис для конструювання комплексного механізму розбудови ефективної логістики товарних ринків формують відтворювальний підхід, концепція діаграми збалансованих переваг, регуляторний підхід та концепція сталого розвитку (рис. 2). Їх сутність та вплив на розбудову ефективних ЛЛТР досліджено в працях $[12,14]$.

Науковим і аналітичним підгрунтям для розробки та впровадження механізмів й інструментів формування ринкової логістики є методичне забезпечення для оцінки поточного стану та «розривів» логістичних процесів товарного ринку, зокрема, авторські методичні положення діагностики ефективності функціонування ЛЛТР за допомогою системи збалансованих кількісно-якісних показників [14]. 


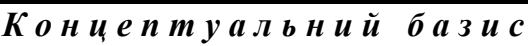

Відтворювальний підхід, концепція діаграми збалансованих переваг, регуляторний підхід, концепція сталого розвитку

\section{ме тодичний базис}

Методичні положення діагностики ефективності функціонування ЛЛТР за допомогою системи збалансованих кількісно-якісних показників стану потокових процесів товарного ринку

Мета комплексного механізму формування ефективної логістики товарного ринку:

Шляхом конструктивного поєднання способів, засобів і методів управління та взаємодії учасників ЛЛТР забезпечити розширене відтворення товароруху в ринку та оптимізацію загальної (ринкової) доданої вартості

\section{Завдання комплексного механізму:}

1. Оптимізація структурної будови логістичних ланцюгів товарного ринку на засадах об'єктивізації розподілу доданої вартості між суб'єктами та ланками ланцюга.

2. Нівелювання (або зменшення) системних і глибинних логістичних «розривів» потокових процесів ринку.

3. Оптимізація потужності руху внутрішніх і зовнішніх товаропотоків ринку.

4. Забезпечення просторово-часового балансування ринкових товарних потоків.

5. Скорочення втрат (часових, матеріальних, трудових та ін.) у процесі товароруху в ЛЛТР.

6. Становлення та розвиток оптимальних форм логістичної взаємодії суб'єктів ринкових ланцюгів і держави на засадах узгодження їх економічних інтересів.

7. Забезпечення доступу малих і середніх товаровиробників до прибуткових ланок ЛЛТР

8. Організація товароруху на стратегічних ринках відповідно до завдань економічної безпеки держави.

9. Стимулювання впровадження Цілей сталого розвитку у всіх ланках ЛЛТР для формування екологічно безпечних ринкових ланцюгів.

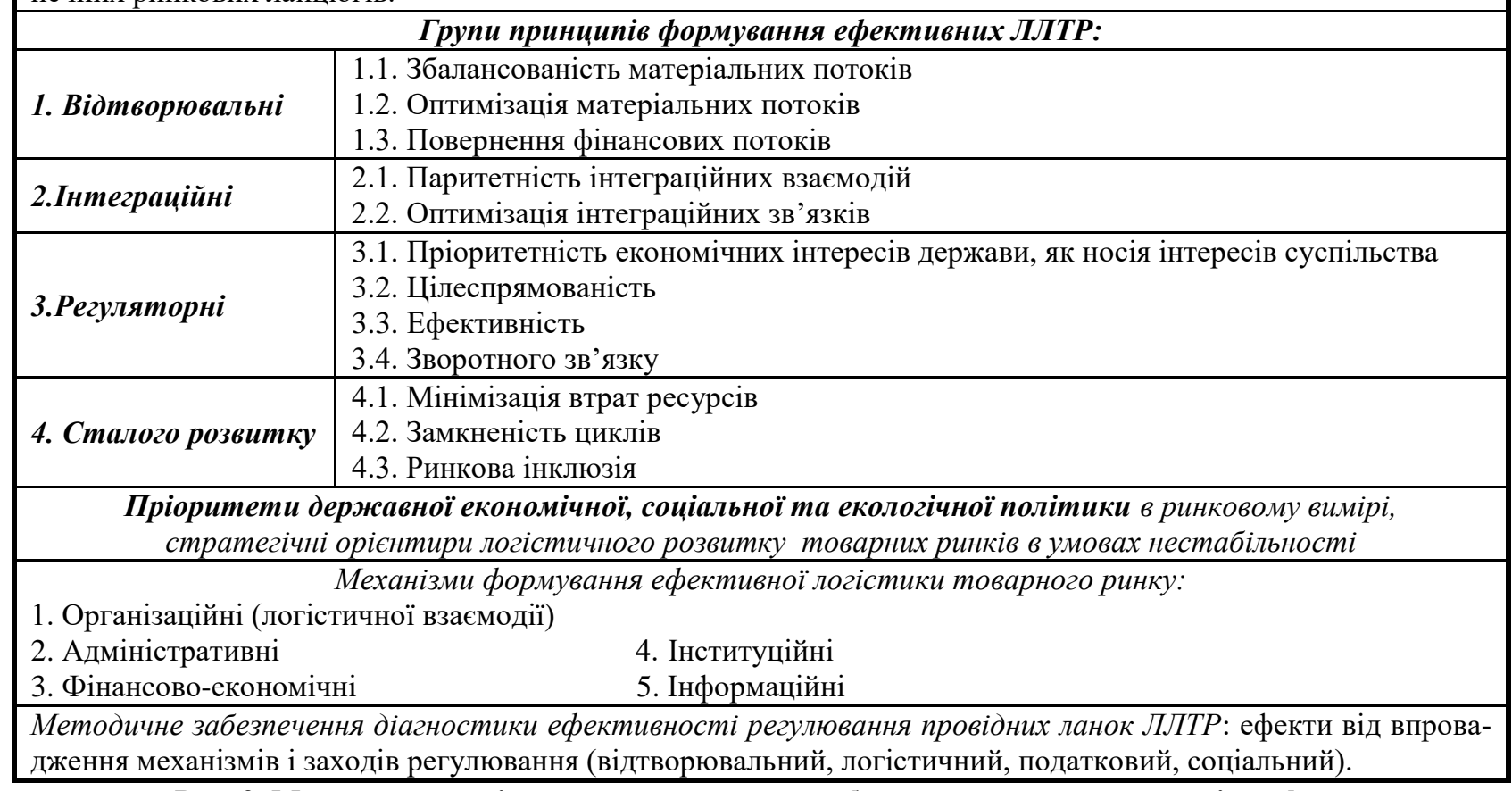

Рис. 2. Мета, завдання і теоретико-методичний базис комплексного механізму формування ефективної логістики товарних ринків*

*авторська розробка

Результати діагностики, проведеної з використанням даних методичних положень, дозволяють обгрунтувати пріоритетні об'єкти управління (системні логістичні «розриви», провідні ланки ринкового ланцюга тощо), на які доцільно спрямувати заходи й методи цілеспрямованого управлінського впливу.

Головна мета комплексного механізму формування ефективної логістики товарних ринків має відтворювальну природу та орієнтована на забезпечення розширеного відтворення товароруху в ринку й оптимізацію загальної (ринкової) доданої вартості, що досягається на основі конструктивного поєднання способів, засобів і методів управління та взаємодії учасників ЛЛТР (див. рис. 2). Враховуючи взаємозалежність і взаємовплив механізмів логістичної взаємодії та управління (див. рис. 1), важливо забезпечити збалансування та координацію цих двох складових комплексного механізму за активної участі державних і профільних інституцій ринку.

Завдання комплексного механізму зорієнтовані на досягнення його головної відтворювальної мети та передбачають, зокрема, оптимізацію структурної будови ЛЛТР, нівелювання (або зменшення) системних логістичних «розривів» потокових процесів ринку, забезпечення просторово-часового балансування товаропотоків, скорочення втрат (часових, ма- 
теріальних, трудових та ін.) у процесі товароруху в ринкових ланцюгах та ін. (див. рис. 2). Одним із найважливіших завдань постає оптимізація структури ЛЛТР на засадах об'єктивізації міжланкового розподілу доданої вартості, що дозволяє вирішити інше завдання - забезпечення доступу малих і середніх товаровиробників до прибуткових ланок ринкових ланцюгів, яке $є$ особливо актуальним для агропродовольчих ринків України.

Оскільки логістична компонента інтегрована у певні організаційні та економічні механізми управління розвитком національної економіки, важливо узгодити завдання логістичного розвитку стратегічних ринків із соціально-економічними пріоритетами держави, забезпечити внесок ринкової логістики у досягнення цих пріоритетів, передусім, у сфері економічної безпеки та сталого розвитку. Тому доцільним є включення до складу завдань організацію товароруху на стратегічних ринках відповідно до завдань економічної безпеки держави, а також стимулювання впровадження Цілей сталого розвитку у всіх ланках ЛЛТР для формування екологічно безпечних ринкових ланцюгів (див. рис. 2). При цьому перше завдання передбачає оптимізацію потужності руху внутрішніх і зовнішніх товаропотоків в ринку, тобто наявна взаємопов'язаність різних завдань.

В ході розробки комплексного механізму формування ефективної логістики товарних ринків доцільно дотримуватися чотирьох груп принципів розбудови ефективних ЛЛТР (відтворювальних, інтеграційних, регуляторних і сталого розвитку), обгрунтованих авторами у дослідженнях [12]. Слід відзначити, що наведені завдання комплексного механізму відповідають певним групам принципів, що підсилює взаємозв'язки між ними.

Комплексний механізм поєднує як організаційні механізми (логістичної взаємодії), так і управлінські, серед яких необхідно виділити адміністративні, фінансово-економічні, інституційні та інформаційні механізми (див. рис. 2). В організаційних та інформаційних механізмах переважають мотиваційностимулюючі заходи, в механізмах інших типів - примусово-обмежувальні методи та нормативно-правова регламентація товароруху в ринках. Для забезпечення стабілізуючого впливу комплексних механізмів на потокові процеси товарних ринків важливим $є$ збалансування стимулюючих і примусово-обмежувальних методів і заходів держави.

Нині управлінський вплив держави на процеси логістизації товарних ринків є мінімальним. Домінують примусово-обмежувальні методи над стимулюючими заходами щодо створення логістичних центрів (зокрема, оптових ринків сільгосппродукції), розвитку оптимальних форм логістичної взаємодії дрібних товаровиробників (наприклад, багатофункціональної кооперації), покликаних забезпечити більш об'єктивний перерозподіл доданої вартості у ланцюгах стратегічних товарних ринків. Формування ефективної ринкової логістики базується в т.ч. на регуляторній групі принципів (див. рис. 2), яка передбачає керованість процесів формування, трансформації та розвитку ЛЛТР і зв’язків між їх ланками.

Глибина, масштаб і тривалість державного регулювання залежать від об'єктів управління, головними 3 яких, на наш погляд, є логістичні «розриви» потокових процесів та провідні ланки ЛЛТР. Регулювання логістичних «розривів», які ринок самостійно не може усунути, передбачає цілеспрямований вплив держави на даний об'єкт з метою відновлення збалансованого безперервного руху наскрізного матеріального потоку та забезпечення розширеного відтворення товароруху в межах ЛЛТР. Даний тип регулювання чинить стабілізуючий вплив на матеріалопровідний ланцюг, дозволяє відновити його міжланкові зв'язки й взаємодії та досягти логістичної цілісності товарного ринку [15].

Управлінський вплив держави на функціонування провідних ланок ЛЛТР або їх розбудову (за умови відсутності) передбачає цільове використання комплексного механізму для активізації діяльності суб'єктів даних ланок, зміни сировинної орієнтації товарних потоків, співвідношення потужності руху внутрішніх і зовнішніх матеріальних потоків, тощо. Даний тип регулювання чинить формуючий вплив на матеріалопровідну систему, сприяє оптимізації структурної будови ринкового ланцюга, поетапному становленню нового ЛЛТР у відповідності до цільових орієнтирів та забезпеченню його ефективного функціонування.

Методичні положення діагностики ефективності регулювання провідних ланок ЛЛТР складають завершальний етап методичного базису комплексного механізму формування ефективної ринкової логістики (див. рис. 2). Метою даних методичних положень $\epsilon$ визначення ступеню (стабілізуючого, нейтрального або деструктивного) регуляторного впливу на потокові процеси провідних ланок ринкових ланцюгів та логістичні «розриви» в ринку, здійснення комплексної оцінки доходності (збитковості) регуляторних заходів держави та прогнозування їх параметрів. Враховуючи, що головним критерієм ефективності ЛЛТР $\epsilon$ оптимізація загальної ринкової доданої вартості, раціональною $є$ оцінка ефективності регуляторних заходів за допомогою зміни цього критерію та пов'язаних $з$ ним показників. Відтак, методичні положення діагностики ефективності регулювання базових ланок ЛЛТР, що пропонуються, базуються на синтезі відтворювального підходу з акцентом на додану вартість та регуляторного підходу з акцентом на податкові ефекти.

Система показників для діагностики ефективності регулювання провідних ланок ринкових ланцюгів узагальнена в таблиці 3. До іiї складу ввійшли дві групи показників, що дозволяють оцінити економічні (відтворювальний, логістичний і податковий) i соціальний ефекти від реалізації регуляторних механізмів, а також рентабельність їх впровадження. Слід зазначити, що економічний ефект має як дохідний, так і витратний вимір. Відтак, до складу економічних ефектів можна включити як відтворювальний і податковий (дохідні), так і логістичні (витратні) ефекти. 
Система показників для діагностики ефективності регулювання провідних ланок ЛЛТР*

\begin{tabular}{|c|c|c|c|}
\hline Групи & Показники & Характеристика & Формули розрахунку \\
\hline \multirow{4}{*}{ 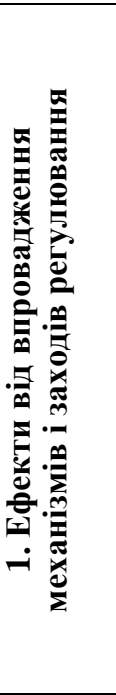 } & $\begin{array}{l}\text { 1.1.Відтворювальний } \\
\text { ефект від впроваджен- } \\
\text { ня регуляторних захо- } \\
\text { дів }\left(\mathbf{E}_{\mathbf{B}}\right)\end{array}$ & $\begin{array}{l}\text { Приріст доданої вартості у ланках } \\
\text { ЛЛТР після реалізації регуляторних } \\
\text { заходів. Відображає ступінь впливу } \\
\text { заходів регулювання на відтворюва- } \\
\text { льні процеси ринку }\end{array}$ & $\begin{array}{l}\mathbf{E}_{\mathbf{B}}=\text { ДВ } \mathbf{2}-\text { ДВ } \mathbf{1}, \text { де } \\
\text { ДВ }, \text { ДВ2, - ринкова додана ва- } \\
\text { ртість до та після реалізації ре- } \\
\text { гуляторних заходів і механізмів }\end{array}$ \\
\hline & $\begin{array}{l}\text { 1.2. Логістичний ефект } \\
\text { від впровадження за- } \\
\text { ходів }\left(\mathbf{E}_{\mathbf{J}}\right)\end{array}$ & $\begin{array}{l}\text { Скорочення логістичних витрат у } \\
\text { ланках ринкових ланцюгів у резуль- } \\
\text { татів впровадження регуляторних } \\
\text { заходів держави. }\end{array}$ & $\begin{array}{l}\mathbf{E}_{\boldsymbol{J}}=\boldsymbol{Л B}_{\mathbf{1}}-\boldsymbol{J B}_{\mathbf{2}}, \text { де } \\
\text { ЛВ }_{1}, \text { ЛВ }_{2},- \text { ринкові логістичні } \\
\text { витрати до та після реалізації } \\
\text { регуляторних заходів і механіз- } \\
\text { мів }\end{array}$ \\
\hline & $\begin{array}{l}\text { 1.3. Податковий ефект } \\
\text { від впровадження за- } \\
\text { ходів }\left(\mathbf{E}_{\boldsymbol{\Pi}}\right)\end{array}$ & $\begin{array}{l}\text { Приріст податкових надходжень у } \\
\text { ланках ЛЛТР після реалізації регуля- } \\
\text { торних заходів }\end{array}$ & $\begin{array}{l}\mathbf{E}_{\boldsymbol{\Pi}}=\mathbf{\Pi}_{\mathbf{2}}-\mathbf{\Pi}_{\mathbf{1}}, \text { де } \\
\Pi_{1,} \Pi_{2}-\text { загальні податкові над- } \\
\text { ходження від суб’єктів ЛЛТР до } \\
\text { та після реалізації заходів дер- } \\
\text { жави }\end{array}$ \\
\hline & $\begin{array}{l}\text { 1.4. Соціальний ефект } \\
\text { від впровадження за- } \\
\text { ходів }\left(\mathbf{E}_{\mathbf{C}}\right)\end{array}$ & $\begin{array}{l}\text { Приріст заробітної плати працівни- } \\
\text { ків у ланках ринкових ланцюгів піс- } \\
\text { ля впровадження регуляторних захо- } \\
\text { дів та механізмів }\end{array}$ & $\begin{array}{l}\mathbf{E}_{\mathbf{C}}=\mathbf{3}_{\mathbf{2}}-\mathbf{3}_{\mathbf{1}}, \text { де } \\
3_{1}, 3_{2},- \text { заробітна плата праців- } \\
\text { ників до та після впровадження } \\
\text { регуляторних заходів }\end{array}$ \\
\hline \multirow{4}{*}{ 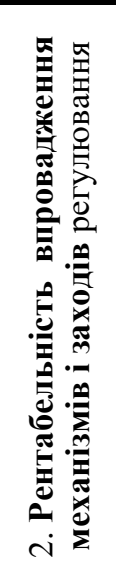 } & $\begin{array}{l}\text { 2.1. Прибуток (збиток) } \\
\text { від впровадження ре- } \\
\text { гуляторних заходів (П) }\end{array}$ & $\begin{array}{l}\text { Різниця між доходами та витратами } \\
\text { держави на реалізацію механізмів і } \\
\text { заходів регулювання }\end{array}$ & $\begin{array}{l}\mathbf{\Pi}=\text { Д - В, де } \\
\text { Д - доходи держави; В - витра- } \\
\text { ти держави на фінансування } \\
\text { впровадження заходів }\end{array}$ \\
\hline & $\begin{array}{l}\text { 2.2. Рентабельність } \\
\text { регулювання } \\
\text { ЛЛТР }\left(\mathbf{P}_{\mathbf{P}}\right) \\
\end{array}$ & $\begin{array}{l}\text { Величина прибутку держави, що } \\
\text { припадає на } 1 \text { грн. витрат на реаліза- } \\
\text { цію механізму регулювання }\end{array}$ & $\begin{array}{l}\mathbf{P}_{\mathbf{P}}=\mathbf{\Pi} / \mathbf{B} \times \mathbf{1 0 0 \%}, \text { де } \\
\text { П - прибуток держави від реалі- } \\
\text { зації заходів }\end{array}$ \\
\hline & $\begin{array}{l}\text { 2.3. Відтворювальна } \\
\text { рентабельність регу- } \\
\text { Лювання ЛЛТР }\left(\mathbf{P}_{\mathbf{B}}\right)\end{array}$ & $\begin{array}{l}\text { Величина загальної ринкової доданої } \\
\text { вартості, що припадає на } 1 \text { грн. ви- } \\
\text { трат на реалізацію механізму регу- } \\
\text { лювання }\end{array}$ & $\begin{array}{l}\mathbf{P}_{\mathbf{B}}=\text { ДВ } \mathbf{p} / \mathbf{B} \times \mathbf{1 0 0 \%}, \text { де } \\
\text { ДВ }- \text { загальна сума доданої } \\
\text { вартості, створеної в ЛЛТР піс- } \\
\text { ля впровадження механізму } \\
\end{array}$ \\
\hline & $\begin{array}{l}\text { 2.4. Соціальна рента- } \\
\text { бельність регулювання } \\
\text { ЛЛТР }\left(\mathbf{P}_{\mathbf{C}}\right)\end{array}$ & $\begin{array}{l}\text { Величина ринкової заробітної плати } \\
\text { працівників, що припадає на } 1 \text { грн. } \\
\text { витрат на реалізацію механізму ре- } \\
\text { гулювання }\end{array}$ & $\begin{array}{l}\mathbf{P}_{\mathbf{C}}=\mathbf{3 \Pi _ { \mathbf { P } }} / \mathbf{B} \times \mathbf{1 0 0 \%} \text {, де } \\
\text { ЗП } \\
\text { плати, отральна сума заробітної } \\
\text { ЛЛТР після впрова працівниками } \\
\text { ляторного механізму. }\end{array}$ \\
\hline
\end{tabular}

*Авторська розробка

Перша група діагностичних показників характеризує зміну загальних ринкових показників логістичного ланцюга (доданої вартості, логістичних витрат, податкових надходжень від суб'єктів складових ланок і заробітної плати працівників) у результаті впровадження певного регуляторного механізму або заходу. Базовими показниками цієї групи, які оцінюють ступінь державного впливу на відтворювальні та потокові процеси товарного ринку, є відтворювальний та логістичний ефекти. Відтворювальний ефект визначає приріст загальної доданої вартості в ринковому ланцюгу після впровадження регуляторного механізму або заходу. Логістичний ефект вимірює величину скорочення загальних логістичних витрат у результаті регуляторного впливу на базові ланки ЛЛТР. Податковий ефект визначає приріст податкових надходжень від суб'єктів ЛЛТР після впровадження регуляторних заходів держави і $є$ кількісним виміром їі економічних інтересів.

Соиіальний ефект визначає соціальний результат від регуляторної діяльності держави в ринкових ланцюгах. Як багатогранна категорія, соціальний ефект характеризує підвищення якості життя та добробуту суспільства, покращення умов праці, збереження (зростання) робочих місць тощо. Для його кількісного виміру в методичних положеннях запропоновано використати приріст заробітної плати працівників у ланках ЛЛТР після впровадження регуляторних механізмів та заходів.

Друга група показників об'єднала три види рентабельності регулювання ринкових логістичних ланцюгів (див. табл. 3). Прибуток держави розраховується як різниця між іiі доходами та витратами на реалізацію заходів і $\epsilon$ індикатором доходності або збитковості бюджетної підтримки. Рентабельність регулювання визначає величину прибутку держави, отриманого на 1 грн. вкладених у реалізацію регуляторних механізмів і заходів коштів. Відтворювальна рентабельність регулювання ЛЛТР вимірює обсяг ринкової доданої вартості, що припадає на 1 грн. бюджетних витрат. Соціальна рентабельність регулювання ЛЛТР визначає обсяг заробітної плати працівників, зайнятих у ланках ринкового ланцюга, що припадає на 1 грн. бюджетних витрат, та $є$ індикатором 
реалізації економічних інтересів суспільства.

У цілому система показників для діагностики ефективності регулювання базових ланок ЛЛТР об'єднала 8 показників, які прямо або опосередковано пов'язані із динамікою змін ринкової доданої вартості до та після впровадження регуляторних заходів, оцінюючи зворотну реакцію ланцюгів товарних ринків на управлінський вплив держави. Інформаційною базою для розрахунку показників є офіційні дані Державної служби статистики України, іiі міністерств i відомств, інформаційно-аналітичних служб і агентств тощо. Запропоновані методичні положення діагностики ефективності регулювання базових ланок ринкових ланцюгів дозволяють проводити моніторинг раціонального використання бюджетних коштів, визначати пріоритетні напрями фінансування, здійснювати вибір найбільш ефективного механізму або заходу регулювання із сукупності альтернативних, прогнозувати їх параметри.

Необхідною умовою стабілізуючого впливу держави на логістичні «розриви» та провідні ланки ЛЛТР є забезпечення постійного зворотного зв'язку суб'єктів управління із об'єктом шляхом постійного моніторингу результативності такого цілеспрямованого впливу на стан логістичних процесів певного товарного ринку. У випадку погіршення показників, негативних чи нульових економічних і соціальних ефектів у ринкових ланцюгах, дестабілізуючої дії, держава здійснює коригування механізмів і заходів регулювання, які через певний часовий період знову піддає моніторингу й діагностиці. Відтак, маємо певну циклічність у процесах діагностики та регулювання «розривів» потокових процесів і провідних ланок ЛЛТР.

Висновки та перспективи подальших досліджень. На підставі теоретичного узагальнення виділено чотири підходи до визначення сутності категорії «механізм», обгрунтовано доцільність використання комплексного підходу до теоретичного осмислення та структуризації механізмів формування ефективної логістики товарних ринків, який враховує сукупність взаємодій і взаємовпливів механізмів різних типів. Запропоновано авторське визначення вихідної категорії з акцентом на відтворювальну мету ефективної логістики та ії важливу роль у збалансуванні попиту та пропозиції товарів у просторових і часових межах певного ринку. Наголошено, що реалізація комплексного механізму передбачає поєднання організаційних методів з соціально-економічними, адміністративними та інституційними методами впливу на об'єкт управління.

Досліджено взаємозв'язки та взаємодії меха- нізмів формування ефективної логістики на мікро- та макрорівні, їх різновекторний вплив на процеси товароруху, взаємопроникнення різних методів і способів управління у механізми різних типів. Встановлено, що логістична компонента інтегрована у певні організаційні та економічні механізми управління розвитком національної економіки та їі секторів. Держава, як регулятор розвитку товарних ринків, формує інституційне середовище та розробляє механізми реалізації економічної, екологічної та соціальної політики, які регламентують потокові процеси товарних ринків. Наголошено, що збалансування стимулюючомотиваційних і примусово-обмежувальних заходів держави покликано забезпечити результативність комплексного логістичного механізму.

Розроблено теоретико-методичний базис комплексного механізму формування ефективної логістики товарних ринків, методичні положення діагностики ефективності регулювання провідних ланок ЛЛТР. Головними перевагами запропонованого методичного забезпечення є такі: (1) різнобічна оцінка соціально-економічних ефектів від впровадження регуляторних заходів у контексті реалізації економічних інтересів суб'єктів ЛЛТР, держави та працівників; (2) можливість формування різних сценаріїв управлінського впливу та вибір найбільш ефективного механізму регулювання із сукупності альтернативних, прогнозування їх параметрів; (3) можливість проведення моніторингу раціонального використання бюджетних коштів на основі зворотного зв'язку із об'єктом управління.

Наукова новизна проведеного дослідження полягає в розвитку теоретико-методологічних засад ринкової логістики в частині обгрунтування теоретичного базису механізмів формування ефективної логістики товарних ринків, методичного забезпечення діагностики ефективності регулювання провідних ланок ЛЛТР на основі відтворювального та регуляторного підходів. Теоретичний базис формує наукове підгрунтя для розробки та впровадження комплексних логістичних механізмів на макрорівні. Методичні положення діагностики ефективності регулювання провідних ланок ринкових ланцюгів можуть бути використані органами влади різних рівнів для визначення сукупності ефектів (відтворювального, податкового, логістичного й соціального) від впровадження певних регуляторних механізмів і заходів. Використання теоретико-методичних засад логістичних механізмів для обгрунтування їх складових та оцінки ефективності регуляторних заходів у ланцюгах різних товарних ринків України формує перспективи подальших розробок у даному напрямі.

\section{Література}

1. Бычкова А.Н. Экономический механизм: определение, классификация и применение // Вестник Омского университета. Сер. Экономика. 2010. №4. С.37-43.

2. Измалков С., Сонин К., Юдкевич М. Теория экономических механизмов (Нобелевская премия по экономике 2007 г. часть №1). URL: https://institutiones.com/theories/259--2007-1.html (дата звернення: 20.01.21) 
3. Кульман А. Экономические механизмы / пер. с фр. Островской Е.П. М.: Издат. группа «Прогресс»; «Универс», 1993. 189 c. URL: https://mysocrat.com/book-card/17168-ehkonomicheskie-mvanizmy/ (дата звернення: 20.01.21)

4. Економічна енциклопедія: у трьох томах. Т. 1 / Редкол. С. В. Мочерний (відп. ред.) та ін. К.: ВЦ «Академія», 2000. 864 с.

5. Чаленко А.Ю. О неопределенности термина «механизм» в экономических исследованиях // Економіка промисловості. 2010. №3. С.26-33. URL:http://nbuv.gov.ua/UJRN/econpr_2010_3_6 (дата звернення: 25.01.21)

6. Гурч Л.М. Логістика. Київ: ДП «Видавчничий дім «Персонал», 2008. 560 с.

7. Дикань В.Л., Заєць Г.П. Організаційно-економічне забезпечення ефективної діяльності підприємств: логістичний підхід. Вісник економіки транспорту і промисловості. $2019 . \quad$ №65. С.9-17. doi:10.18664/338.47:338.45.v0i65.159738

8. Слетенко О.В. Механізм управління логістичною системою підприємства // Вісн. нац. ун-ту «Львів. Політехніка». 2008. № 628. С. 494-498.

9. Пономаренко В.С., Таньков К.М., Лепейко Т.І. Логістичний менеджмент / за ред. В.С. Пономеренко. Х.: ВД «НЖЕК», 2010. $440 \mathrm{c.}$

10. Философский энциклопедический словарь. М.: ИНФРА-М, 1998. 576 с.

11. Нікішина О.В., Діленко В.О., Тараканов М.Л. Логістичний фактор трансформації теоретичних положень функціонування товарних ринків // Проблеми економіки. 2019. №3 (41). C.164-170. URL: https://www.problecon.com/export_pdf/problems-of-economy-2019-3_0-pages-164_170.pdf (дата звернення 1.02.2021). doi:10.32983/2222-0712-2019-3-164-170

12. Буркинський Б.В., Лисюк В.М., Тараканов М.Л. та ін. Методологічні засади формування ефективної логістики товарних ринків: монографія. Одеса: ІПРЕЕД НАН України, 2020. 200 с.

13. Господарський кодекс України. Ред. від 16.10.2020, підстава - 124-IX. URL: https://zakon.rada.gov.ua/laws/show/436-15/ed20201016 (дата звернення 1.02.2021)

14. Буркинський Б.В., Нікішина О.В. Діагностика ефективності логістичних ланцюгів товарних ринків: наук. доповідь. Одеса: ІПРЕЕД НАН України, 2020. 75 с.

15. Нікішина О. В., Тараканов М.Л. Теоретико-методичні засади логістичних «розривів» у ланцюгах товарних ринків // Економіка харчової промисловості. 2020. Т.12, вип. 4. С. 3-16. doi: 10.15673/fie.v12i4.1906

Стаття надійшла 5.02.2021

Стаття прийнята до друку 19.02.2021

Доступно в мережі Internet 18.04.2021

\author{
Nikishyna 0. \\ Doctor of Economics, Senior Researcher \\ Head of Department of Market Mechanisms and Structures \\ Institute of Market Problems and Economic \& Ecological Research \\ of National Academy of Sciences of Ukraine \\ Frantsuzskiy boulevard, 29, Odesa, Ukraine, 65044 \\ E-mail: ksenkych@gmail.com \\ ORCID ID: 0000-0002-7172-3551
}

\title{
THEORETICAL BASIS OF MECHANISMS FOR THE FORMATION OF EFFICIENT LOGISTICS OF COMMODITY MARKETS
}

The article is devoted to substantiation of theoretical bases of mechanisms of formation of effective logistics of commodity markets on the basis of the reproduction approach. There are four approaches to defining the essence of the economic category of «mechanism», namely: (1) organizational and coordination; (2) managerial; (3) evolutionary; (4) complex. Based on a comprehensive approach, the author's definition of the category «mechanism for the formation of efficient logistics of commodity markets» with an emphasis on the reproduction purpose of market logistics has been proposed. The comparative analysis of mechanisms of formation of market logistics of different types has been carried out: logistic interaction, managerial and complex. It has been emphasized that the implementation of a comprehensive mechanism involves a combination of organizational methods with socio-economic, administrative and institutional methods of influencing the object of management.

The relationships and interactions of logistics mechanisms at the micro and macro levels, the interpenetration of different methods and ways of management in mechanisms of different types have been studied. It has been emphasized that the logistics component is integrated into certain organizational and economic mechanisms for managing the development of the national economy and its sectors. The state, as a regulator 
of commodity markets, forms the institutional environment and develops mechanisms for implementing economic, environmental and social policies that regulate the flow processes of commodity markets.

The theoretical and methodological basis of the complex mechanism of formation of effective logistics of commodity markets has been developed. The expediency of the managerial influence of the state has been substantiated, on the one hand, on the logistical «gaps» of the flow processes of commodity markets to ensure their logistical integrity, on the other hand, on the leading links of strategic markets to optimize the structural construction of the market chain. Emphasis is placed on the cyclical nature of the process of diagnosis and regulation of "gaps» and the leading links in the chain, the importance of providing feedback between the subject and the object of control. Methodical provisions of diagnostics of efficiency of regulation of leading links of market chains on the basis of synthesis of reproduction and regulatory approaches has been developed.

Key words: commodity market, logistics chain, mechanism, leading link, regulation, efficient logistics, added value.

\section{References}

1. Byichkova, A. N. (2010). Ekonomicheskiy mehanizm: opredelenie, klassifikatsiya i primenenie. Vestnik Omskogo universiteta, (4), 37-43.

2. Izmalkov, S., Sonin, K., \& Yudkevich, M. (2007). Teoriya ekonomicheskih mehanizmov (Nobelevskaya premiya po ekonomike 2007 g. chast \#1). Retrieved January 20, 2021, from https://institutiones.com/theories/259-2007-1.html

3. Kulman, A. (1993). Ekonomicheskie mehanizmyi. (E. P. Ostrovskoy, Trans.). Moscow: Izdat. gruppa «Progress»; «Univers». Retrieved January 20, 2021, from https://mysocrat.com/book-card/17168-ehkonomicheskiemvanizmy/

4. Mochernyi, S. V. (Ed.). (2000). Ekonomichna entsyklopediia (Vol. 1). Kyiv: VTs «Akademiia».

5. Chalenko, A. Yu. (2010). O neopredelennosti termina «mehanizm»v ekonomicheskih issledovaniyah. Ekonomika promyslovosti, (3), 26-33. Retrieved January 25, 2021, from http://nbuv.gov.ua/UJRN/econpr_2010_3_6

6. Hurch, L. M. (2008). Lohistyka. Kyiv: DP «Vydavchnychyi dim «Personal».

7. Dykan, V. L., \& Zaiets, H. P. (2019). Orhanizatsiino-ekonomichne zabezpechennia efektyvnoi diialnosti pidpryiemstv: lohistychnyi pidkhid. Visnyk ekonomiky transportu $i$ promyslovosti, (65), 9-17. doi:10.18664/338.47:338.45.v0i65.159738

8. Yeletenko, O. V. (2008). Mekhanizm upravlinnia lohistychnoiu systemoiu pidpryiemstva. Visn. nats. un-tu «Lviv. Politekhnika», (628), 494-498.

9. Ponomarenko, V. S., Tankov, K. M., \& Lepeiko, T. I. (2010). Lohistychnyi menedzhment. (V. S. Ponomerenko, Ed.). X.: VD «INZhEK».

10. Moscow: INFRA-M. (1998). Filosofskiy entsiklopedicheskiy slovar.

11. Nikishyna, O. V., Dilenko, V. O., \& Tarakanov, M. L. (2019). Lohistychnyi faktor transformatsii teoretychnykh polozhen funktsionuvannia tovarnykh rynkiv. Problemy ekonomiky, (3(41)), 164-170. Retrieved February 01, 2021, from https://www.problecon.com/export_pdf/problems-of-economy-2019-3_0-pages-164_170.pdf doi:10.32983/2222-0712-2019-3-164-170

12. Burkynskyi, B. V., Lysiuk, V. M., \& Tarakanov, M. L. (2020). Metodolohichni zasady formuvannia efektyvnoi lohistyky tovarnykh rynkiv. Odesa: IPREED NAN Ukrainy.

13. Hospodarskyi kodeks Ukrainy vid 16.10.2020. (2020). Retrieved February 01, 2021, from https://zakon.rada.gov.ua/laws/show/436-15/ed20201016

14. Burkynskyi, B. V., \& Nikishyna, O. V. (2020). Diahnostyka efektyvnosti lohistychnykh lantsiuhiv tovarnykh rynkiv. (rep.). Odesa: IPREED NAN Ukrainy.

15. Nikishyna, O., \& Tarakanov, M. (2020). Theoretical and methodical bases of logistic «gaps» in the chains of commodity markets. Food Industry Economics, 12(4), 3-16. doi: 10.15673/fie.v12i4.1906

Received 5 February 2021

Approved 19 February 2021

Available in Internet 18.04.2021

Цитування згідно ДСТУ 8302:2015

Нікішина О. В. Теоретичний базис механізмів формування ефективної логістики товарних ринків // Економіка харчової промисловості. 2021. Т.13, вип. 1. С. 12-23.

Cite as APA style citation

Nikishyna, O. (2021). Theoretical basis of mechanisms for the formation of efficient logistics of commodity markets. Food Industry Economics, 13(1), 12-23. 